Jurnal Onoma: Pendidikan, Bahasa dan Sastra

ISSN 2443-3667

PBSI FKIP Universitas Cokroaminoto Palopo

Volume 5 Nomor 1

\title{
TRANSKRIPSI FONETIS CERITA RAKYAT MASSENREMPULU
}

\author{
Suparman \\ Program Studi Pendidikan Bahasa dan Sastra Indonesia \\ suparman@uncp.ac.id
}

\begin{abstract}
Abstrak
Tujuan penelitian ini adalah untuk mendeskripsikan dan menjelaskan sistem fonetis bahasa Massenrempulu dalam cerita rakyat. Data penelitian ini berupa cerita tentang Bellang Langu. Data dianalisis dengan menggunakan metode padan dibantu dengan aplikasi IPA (International Phonetic Association). Hasil penelitian menunjukkan bahwa Bahasa massenrempulu mengenal 5 buah vocal, yakni:Vokal tinggi : /i u/, Vokal sedang : /e o/, Vokal rendah : /a/. Pada cerita rakyat Bellang Langi fonem-fonem yang terdapat dalam cerita tidak ada satu pun fonem yang menjadi alofon dari fonem lain. Dalam cerita rakyat Bellang Langi terdapat beberapa fonem di antaranya konsonan bahasa massenrempulu mengenal 19 buah konsonan sedangkan semi vokal hanya terdapat satu fonem. Secara keseluruhan bahasa massenrempulu mengenal ada 24 fonem segmental.
\end{abstract}

Kata kunci: fonologi, fonetik, bahasa Massenrempulu

\section{PENDAHULUAN}

\section{Latar Belakang}

Perkataan Massenrempulu mulanya hanya digunnakan untuk menyatakan wilayah kemudian digunakan pula untuk menyatakan bahasa, tetapi tidak digunakan untuk menyatakan manusia. Pemakai bahasa ini menyatakan diri mereka sebagai orang Endekan, Duri, dan Maiwa. Setelah zaman kemerdekaan, perkataan Massenrumpulu sudah digunakan dalam organisasi kemasyarakatan seperti Himpunan Keluarga Massenrempulu dan Himpunan Pelajar Mahasiswa Massenrempulu.

Wilayah Massenrempulu itu mulanya suata persekutuan tujuh kerajaan yang dikenal sebagai" Pitu Massenrempulu” yang terdiri dari Endekan, Kassa, Batulappa, Maiwa, Duri, Letta, dan Baringin. Kedua kerajaan terakhir kemudian menyerang Endekan, tetapi dibalas oleh Endekan bersama persekutuannya dengan bantuan Sidenreng. Letta dan Baringin dideglarasikan dan tinggal lima kerajaan yang merupakan "Lima Massenrempulu". 
Jurnal Onoma: Pendidikan, Bahasa dan Sastra

PBSI FKIP Universitas Cokroaminoto Palopo

Volume 5 Nomor 1

Setelah melalui beberapa proses pada tahun 1912 dibentuk onderfalding Enrekang yang terdiri dari Endekan, Maiwa, Alla, Maluwah, dan Buttu Batu. Mulai tahun 1960 dibentuk kabupaten Enrekang yang terdiri dari lima kecamatan yaitu Alla. Anggeraja, Baraka, Enrekang, dan Maiwa.

Bahasa massenrempulu hingga saat ini masih tetap berperan sebagai alat penghubung dalam berbagai kehidupan masyarakat dan merupakan pendukung kebudayaan daerah Massenrempulu yang telah memiliki sejarah dan tradisi yang cukup lama dan terus berkembang hingga saat ini. Tradisi lama tersebut meliputi bidang seni, hukum, ekonomi, dan budaya. Dari sejarah dan tradisi ini dapat dilihat bahwa bahasa Massenrempulu senantiasa dipelihara dan dikembangkan dengan baik oleh penuturnya.

Bahasa Massenrempulu tidak luput dari kajian ilmu linguistik dalam hal masalah fonologi atau bunyi bahasa. Ilmu yang menyelidiki dan berusaha merumuskan secara teratur tentang cara bunyi terbentuk, frekuenssi, dan intensitasnya disebut fonetik. Hal ini berbeda dengan fonologi sebagai cabang linguistik yang membicarakan bunyi bahasa dari segi fungsinya, yakni bunyi bahasa yang mapu membedakan makna suatu kata dengan kata lain.

Seperti kita ketahui bahwa Indonesia memiliki keanekarangaman bahasa dengan karakteristik dan perbedaannya masing-masing. Bahasa-bahasa tersebut memiliki daya tarik yang kuat bagi para peneliti bahasa untuk mengetahui bahasa tersebut (Suparman \& Charmilasari, 2016)

Dari berbagai identitas di daerah Massenrempulu, terdapat perbedaan yang khas antara dialek yang di masyrakat. Hal ini menjadi menarik dalam perkembangan daerah Massenrepulu, terutama dari segi variasi dialek yang ada di daerah tersebut.

\section{Rumusan Maslah}

Bagaimana Transkripsi Fonetis dalam Cerita Rakyat Masyarakat Massenrempulu?

\section{LANDASAN TEORI}

Salah satu asumsi teoritis dasar tentang fonologi ialah bahwa tuturan-tuturan dapat dilambangkan sebagai suatu deretan satuan diskret. Oleh karena asumsi itu, kita dapat 
Jurnal Onoma: Pendidikan, Bahasa dan Sastra

PBSI FKIP Universitas Cokroaminoto Palopo

Volume 5 Nomor 1

dapat berbicara tentang segmen tersendiri dan deretan segmen, serta mengembangkan notasi yang menggunakan symbol-simbol diskret untuk melambangkan tuturan-tuturan.

Fonologi adalah bidang linguistik yang mempelajari dan menganalisis serta membicarakan runtutan bunyi-bunyi bahasa (Chaer, 2003; 102), yang merupakan mata kuliah wajib bagi mahasiswa bahasa dan sastra.

Fonologi adalah bagian tata bahasa atau bidang ilmu bahasa yang menganalisis bunyi bahasa secara umum. Istilah fonologi, yang berasal dari gabungan kata Yunani phone 'bunyi' dan 'logos' tatanan, kata, atau ilmu' dlsebut juga bidang ini meliputi dua bagian.Fonetik, yaitu bagian fonologi yang mempelajari cara menghasilkan bunyi bahasa atau bagaimana suate bunyi bahasa diproduksi oleh alat ucap manusia.

Objek kajian fonologi adalah fonetik dan fonemik. Fonetik adalah ilmu yang menyelidiki dan menganalisa bunyi-bunyi ujaran yang dipakai dalam tutur, serta mempelajari bagaimana menghasilkan bunyi-bunyi tersebut dengan alat ucap manusia (keraf, 1991; 30), sesuai fungsinya sebagai pembeda arti. Jadi dalam kajian fonetik akan dibahas segala macam bunyi yang dapat dihasilkan oleh alat ucap serta bagaimana tiap-tiap bunyi itu dilaksanakan. Sedangkan, fonemik adalah ilmu yang mempelajari bunyi ujaran dalam fungsinya sebagai pembeda arti (Keraf, 1991;30). Maka dalam fonemik akan dipelajari dan diselidiki kemungkinan-kemungkinan bunyi ujaran mana yang dapat mempunyai fungsi sebagai pembeda arti. Bunyi ujaran yang bersifat netral, atau masih belum terbukti membedakan arti disebut fona, sedang fonem ialah satuan bunyi ujaran terkecil yang membedakan arti. Variasi fonem karena pengaruh lingkungan yang dimasuki disebut alofon. Gambar atau lambang fonem dinamakan huruf. Jadi fonem berbeda dengan huruf.

Unluk menghasilkan suatu bunyi atau fonem, ada tiga unsur yang penting yaitu:

1 udara,

2. artiikulator atau bagian alat ucap yang bergerak, dan 3. titik artikulasi atau bagian alat ucap yang menjadi titik sentuh artikulator. 
Jurnal Onoma: Pendidikan, Bahasa dan Sastra

PBSI FKIP Universitas Cokroaminoto Palopo

Volume 5 Nomor 1

\section{METODE PENELITIAN}

Pendekatan penelitian yang digunakan peneliti adalah pendekantan kualitatif. Pendekatan kualitatif merupakan prosedur penelitian yang menghasilkan kosakata dasar yang berupa kata-kata tertulis atau lisan. Sejalan dengan pendekatan yang digunakan maka metode yang digunkan dalam penlitian ini adalah metode deskriptif. Sumber data dalam penilitian ini adalah data berupa tuturan dalam cerita rakyat masyarakat Massenrempulu. Teknik pengumpulan data digunakan teknik catat, sistem pencatat menggunakan transkripsi fonetis. Teknik analisi data dengancara Mengklasifikasi data transkripsi fonetis, mengidentifikasi setiap perbedaan dalam tataran fonologis, memindahkan data yang sudah diklasifikasi.

\section{PEMBAHASAN}

\section{A. VOKAL BAHASA MASSENREMPULU}

Fonem vokal adalah fonem yang dalam pengucapannya menyebabkan pita suara bergetar dan udara yang keluar dari paru-paru tidak mendapat rintangan atau halangan, sedangkan kualitasnya ditentukan oleh tiga faktor: tinggi rendahnya posis lidah, bagian lidah yang dinaikkan, dabn bentuk bibr pada pembentikan vokal itu.

Pada saat vokal diucapkan, lidah dapat dinaikkan atau diturunkan bersama rahang. Bagian lidah yang dinaikkan atau diturunkan itu terdapat di bagian depan, tengah, atau belakangnya. Selain posisi lidah seperti disebutkan di atas, kualitas vokal juga dipengaruhi oleh bentuk bibir.

Bahasa Massenrempulu memiliki lima vokal, yaitu: /i/, /u/, /e/, /o/, dan /a/. kelima vokal itu berbeda satu sama lain yang lainnya disebabkan oleh perubahan yang terjadi di dalam daerah rongga mulut, gerakan lidah, dan bentuk lidah. Berdasarkan gerakan alat ucap, vokal Massenrempulu dapat dibedakan sebagai berikut:

a. Berdasarkan tinggi rendahnya posisi lidah:

Vokal tinggi : i, $\mathrm{u}$

Vokal tengah : e, o

Vokal rendah : a

b. Berdasarkan maju mundurnya gerakan lidah: 
Jurnal Onoma: Pendidikan, Bahasa dan Sastra

PBSI FKIP Universitas Cokroaminoto Palopo

Volume 5 Nomor 1

Vokal depan : i.e

Vokal pusat $\quad:$ a

Vokal belakang $\quad: \mathrm{u}, \mathrm{o}$

c. Berdasarkan bundar lebarnya bibir:

Vokal bundar $\quad:$ u,o

Vokal tak bundar : i, e

1. Klasifikasi vokal

Klasifikasi vokal ini dimaksudkan untuk memperlihatkan dengan jelas pembagian daerah artikulasi setiap vokal dalam bahasa Massenrempulu. Dapat dilihat klasifikasi sebagai berikut:

Tabel

Klasifikasi Vokal

\begin{tabular}{|l|c|c|c|}
\hline \multirow{2}{*}{$\begin{array}{l}\text { Posisi } \\
\text { lidah/bentuk bibir }\end{array}$} & Depan & \multicolumn{2}{|l|}{ Belakang } \\
\cline { 2 - 4 } & Tak Bulat & Tak Bulat & Bulat \\
\hline Tinggi & I & & U \\
\hline Tengah & E & & 0 \\
\hline Rendah & & a & \\
\hline
\end{tabular}

\section{Distribusi vokal}

Distribusi vokal adalah penyebaran vokal tertentu di dalam menempati suatu posisi dalam kata. Penyebaran itu ada tiga kemungkinanya, yaitu pada awal,tengah, dan akhir kata. Ketiga posisi ini dapat diduduki oleh vokal-vokal bahasa Massenrempulu.

\section{KONSONAN MASSENREMPULU}

Konsonan bahasa Massenrempulu dapat diedintifikasi atau diberi nama dengan menyebut lebih dahulu artikulasinya, kemudian dasar ucapan, rongga ujaran, dan akhirnya keadaan pita suara. Dengan demikian, konsonan bahasa Massenrempulu dalam cerita Bellang Langi sebagai berikut: 
Jurnal Onoma: Pendidikan, Bahasa dan Sastra

PBSI FKIP Universitas Cokroaminoto Palopo

Volume 5 Nomor 1

1. fonem /m/ adalah konsona nasal, bilabial, sengau bersuara. Yang terdapat dalam cerita bellang langi, misalnya: macora, kampong, mesa dan sebagainya. Konsonan ini hanya dapat berdistribusi pada awal dan tengah saja

2. fonem /p/ adalah konsonan letupan, bilabial, tak bersuara. Yang terdapat dalam cerita ini, misalnya: pallingkana, Pa'kampong, dll. Konsonan ini hanya dapat berdistribusi di awal dan tengah saja

3. fonem /b/ adalah konsona letupan, bilabial, oral, bersuara. Dalam cerita ini, misalnya: banggi, Ribura, dll. Konsonan ini hanya dapat berdistribusi di awal dan tengah saja.

4. fonem /w/ adalah semivokal, bilabial, bersuara. Dalam cerita ini: waktu, dalam cerita ini semivokal $w$ hanya berdistribusi pada awala.

5. fonem /n/ adalah konsonan nasal, alveolar, sengau, bersuara. nai, langi, ningan

6. fonem /t/ adalah konsonan letupan alveolar, tak bersuara. tau, patarru.

7. fonem /d/ adalah konsonan letupan, alveolar, bersuara: deen, lindona

8. fonem /s/ adalah konsonan desis, alveolar, tak bersuara: sanga

9. fonem /l/ adalah konsonan sampingan, alveolar, bersuara: luminkai dan kollan

10. fonem /r/ adalah konsonan getar, alveolar, bersuara: rundun dan patarru

11. fonem / ñ / adalah konsonan nasal, palatal, sengau, bersuara: manyaman

12. fonem /c/ adalah konsonan paduan, palatal, tak bersuara: cindakturi dan macora

13. fonem /j/ adalah konsonan paduan, palatal, bersuara: jio dan malajai

14. fonem / k/ adalah konsonan letupan, velar, tak bersuara: kampong dan cindakturi

15. fonem /g/ adalah konsonan letup, velar, bersuara: gajai, disangai dan Puang

16. fonem /q/ adalah konsonan letupan, glottal, tak bersuara: lo'lok

17. fonem /h/ adalah konsonan paduan, glottal, tak bersuara: daerah

Bahasa Mssenrempulu mengenal 19 buah konsonan, dalam cerita Bellang Langi hanya terdapat 17 buah konsonan sedangkan konsonan /y/dan /y/ tidak terdapat dalam cerita Bellang Langi. Berdasarkan distribusinya konsonan bahasa Massenrempulu hanya tiga yang dapat berdistribusi di awal, tengah dan akhir yakni: konsonan/n/, /y/ dan /k/ sedangkan yang lainnya hanya dapat berdistribusi pada awal dan tengah saja. 
Jurnal Onoma: Pendidikan, Bahasa dan Sastra

PBSI FKIP Universitas Cokroaminoto Palopo

Volume 5 Nomor 1

Selain konsonan yang dikemukakan, terdapat pula geminasi. Empat di antaranya berkontras dengan paralelnya.

$\begin{array}{lll}\text { /p/: rapo } & \text { x rappo } & \text { 'rapuh-kacang' } \\ \text { /k/: aka' } & \text { x akka' } & \text { 'palma-angkat' } \\ \text { /r/: barang } & \mathrm{x} \text { barrang } & \text { 'barang- kemarau' } \\ \text { /l/: balang } & \mathrm{x} \text { ballang } & \text { 'paru-paru - belang' }\end{array}$

Dalam cerita Bellang Langi hanya terdapat dua geminansi berkontras dengan paralelnya, yakni:

/r/: toro $\quad \mathrm{x}$ torro 'keras-tinggal'

/l/: bela $\quad \mathrm{x}$ bellang 'babat-sangat jauh'

Sedangkan geminasi yang tidak berkontras dengan paralelnya adalah: /t/ :boti x botting 'kentut-menikah'

Secara garis besar bahasa Massenrempulu mengenal 24 fonem segmental, namun tidak semua fonem segmental memiliki kesamaan posisi. Fonem /q/ hanya dapat ditemui di posisi inisial. Ke-24 fonem itu ditentukan pada posisi medial. Fonem /q k h n y i u e o a/ menpati posisi final. Khusus dialaek Endekan fonem /q/ biasa tampil bersama dengan nasal /n/ di posisi final.

\section{TRANSKRIPSI FONETIS}

\section{Bellang Langi}

Dikishakan dahulu kala ada seorang pria berwajah sangat bersinar. Karena ha itu, ia diberi nama Bellang Langi. Konon, Bellang Langi tururn dari langit melalui Gunung Bamba Puang. Karena wajahnya yang sangat bersinar sehingga orang-orang menyebutnya Bellang Langi.

Dari gunung bamba puang ia berjalan ke arah timur mencari tempat yang lanyak untuk ditinggali. Akhirnya, Ia tiba di sebuah desa yangs ekarang disebut desa Bolang. Namun, Ia hanya beberapa hari disana karena merasa kurang nyaman. Ia meneruskan perjalannya dan tiba pada suatu desa. Penduduk di desa tersebut ketakutan melihat wajah Bellang Langi karena sangat bersinar. Oleh sebab itu, desa ini bernama desa kalajak 
Jurnal Onoma: Pendidikan, Bahasa dan Sastra

PBSI FKIP Universitas Cokroaminoto Palopo

Volume 5 Nomor 1

Kemudian, Ia melanjutkan pejalananya menyususri sebuuah sungai. Penduduk setempat menyebutnya salu alu-alu (sungai alu-alu). Di sana Ia menamukan sebuah sumur yang bernama kollan rano tepatnya di sekitar daerah baroko.

Ia membangun sebuah gubuk dan menetapa di sekitar sumur tersebut. Pada suatu hari muncullah seorang gadis yang sanagt cantik nan jelita darai dalam sumur. Gadis itu bernama takombong ribura, mereka melewati hari demi hari dan saling mencintai. Akhirnya, mereka menikah dan menbina sebuah keluarga. Dari pernikahan tersebut lahirnyaah 3 orang putra yaitu Pata langi, kila langi, dan londong langi.

Kla langi dan londong langi kembali ke lurrah, tempat pertama kali bellang langi turun dari langit. Mereka menetap pada daerah tersebut. Sedangkan pata langi memilih menetap di daerah baroko setelah menikahi seorang gadis. Yang bernama bunga kaise. Mmereka memilki seorang putra Sondong Langi.

Generasi sondong langi inilah yang mulai bersanak saudara pada daerah tersebut. Masyrakat menganggap bahwa mereka adalah keturunan dari bellang langi, pria yang turun d ari langit.

$$
\text { [bellay] [lani] }
$$

[ia] [tonna] [anok] [deen] [curita] [pea] [muane] [man] [lindo] [macora]. [saya] [macora] [gajai] [lindona] [na] [disani] [bellay] [lani[. [konon], [ia] [tee] [bellay] [layi] [mellao] [jio] [mai] [lani] [nola] [jio] [buntu] [bamba] [pua]. [saya] [macora] [gajai] [lindona] [nasayai] [tau] [bellan] [lani].

[jio] [buntu] [bamba] [puan] [luminkai] [lako] [arah] [timur] [tiro] [ninan] [to] [bisa] [di'ni] [torro]. [Ia] [tonna] [anu'mu] [timbai] [jio] [mesa] [paykampon] [to] [nasayai] [tau] [too] [kua] [kampoy] [bolay]. [tapi], [cindakturi] [jio] [saya] [tay] [mañaman] [bangi] [na] [sakdin]. [na] [patarru] [omi] [pallinkana] [na] [nampa] [omo] [mesa] [kampon]. [ia] [to] [paykampon] [jio] [njo] [kampon] [malajai] [kitai] [bellay] [layi] [saya] [macora] [gajai] [lindona]. [na] [ia] [mo] [na] [disayai] [jio] [kampon], [kampoy] [kalaja].

[apa] [tonna] [anumu] [na] [patarru] [omi] [pallinkana] [rundun] [birin] [salu]. [paykampon] [kua] [ka] [salu] [alu-alu]. [jiomo] [njo] [na] [nampa] [bubun] [to] [disaya] [kollan] [rano] [jio] [daera] [baroko].

[bellan] [lani] [kabuami] [bola-bola] [biccu] [na] [torro] [mannannuyan] [jio] [njo] [sade] [bubun]. [deen] [pissen] [waktu] [deen] [pea] [baene] [tammaka] [lotlok] [ollon] 
Jurnal Onoma: Pendidikan, Bahasa dan Sastra

PBSI FKIP Universitas Cokroaminoto Palopo

Volume 5 Nomor 1

[jio] [sakde] [bubun]. [Ia] [tee] [pea] [baene] [disana] [takomboy] [ribura], [na] [olaimi] [to] [allo] [demi] [allo] [na] [sampenna] [bottini]. [ia] [tee] [kabottinanna] [jadianni] [pea] [muane] [tallu] [to] [disana] [pata] [lani], [kila] [lani], [na] [londong] [lani].

[kila] [lani] [sola] [londoy] [lani] [pole] [polei] [lako] [kampon] [lura], [ia] [to] [pammulanna] [na] [nii] [bellan] [lani] [mellao] [jio] [ma] [lani]. [torro] [mia] [ia] [mannannuyan] [jio] [njo] [daera]. [na] [ia] [to] [pata] [lani] [na] [pillei] [mia] [torro] [mannanuyan] [jio] [daera] [baroko] [tonna] [manka] [bottoyi] [pea] [baene] [to] [disanan] [buya] [kaise]. [na] [jadiaan] [pea] [muane] [disana] [sondon] [lani].

[Ia] [tee] [keturunanna] [sondon] [lani] [mammulami] [siala-ala] [jio] [njo] [daera]. [na] [ia] [to] [pankampon] [na] [kua], [kua] [keturunanan] [nai] [bellan] [lani], [to] [pea] [muane][mellao] [jio] [mai] [lani].

\section{Bagan Fonetis Bahasa Massenrempulu}

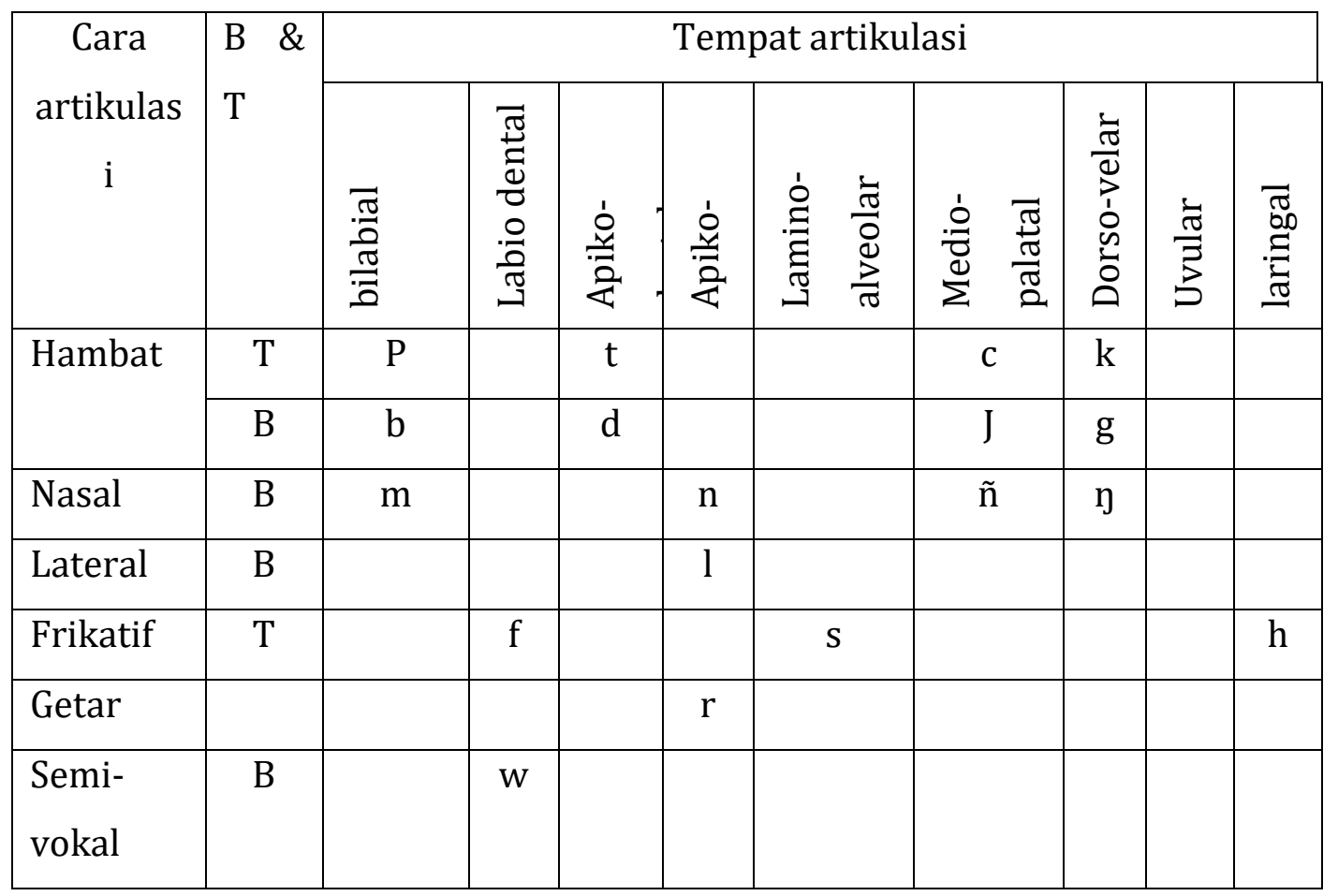


Jurnal Onoma: Pendidikan, Bahasa dan Sastra

PBSI FKIP Universitas Cokroaminoto Palopo

Volume 5 Nomor 1

Bagan Vokal Bahasa Massenrempulu

\begin{tabular}{|l|c|c|c|}
\hline \multirow{2}{*}{$\begin{array}{l}\text { Posisi } \\
\text { lidah/bentuk bibir }\end{array}$} & Depan & \multicolumn{2}{|l|}{ Belakang } \\
\cline { 2 - 4 } & Tak Bulat & Tak Bulat & Bulat \\
\hline Tinggi & I & & u \\
\hline Tengah & E & & o \\
\hline Rendah & & a & \\
\hline
\end{tabular}

ANALISIS

Pasangan bunyi yang mencurigakan dalam cerita rakyat Massenrempulu, dapat dilihat di bawah ini:

$t-c, \quad c-k, \quad d-j, \quad j-g$

$p-b, \quad t-d, \quad c-j, \quad k-g$

$m-n, \quad \tilde{n}-\eta$

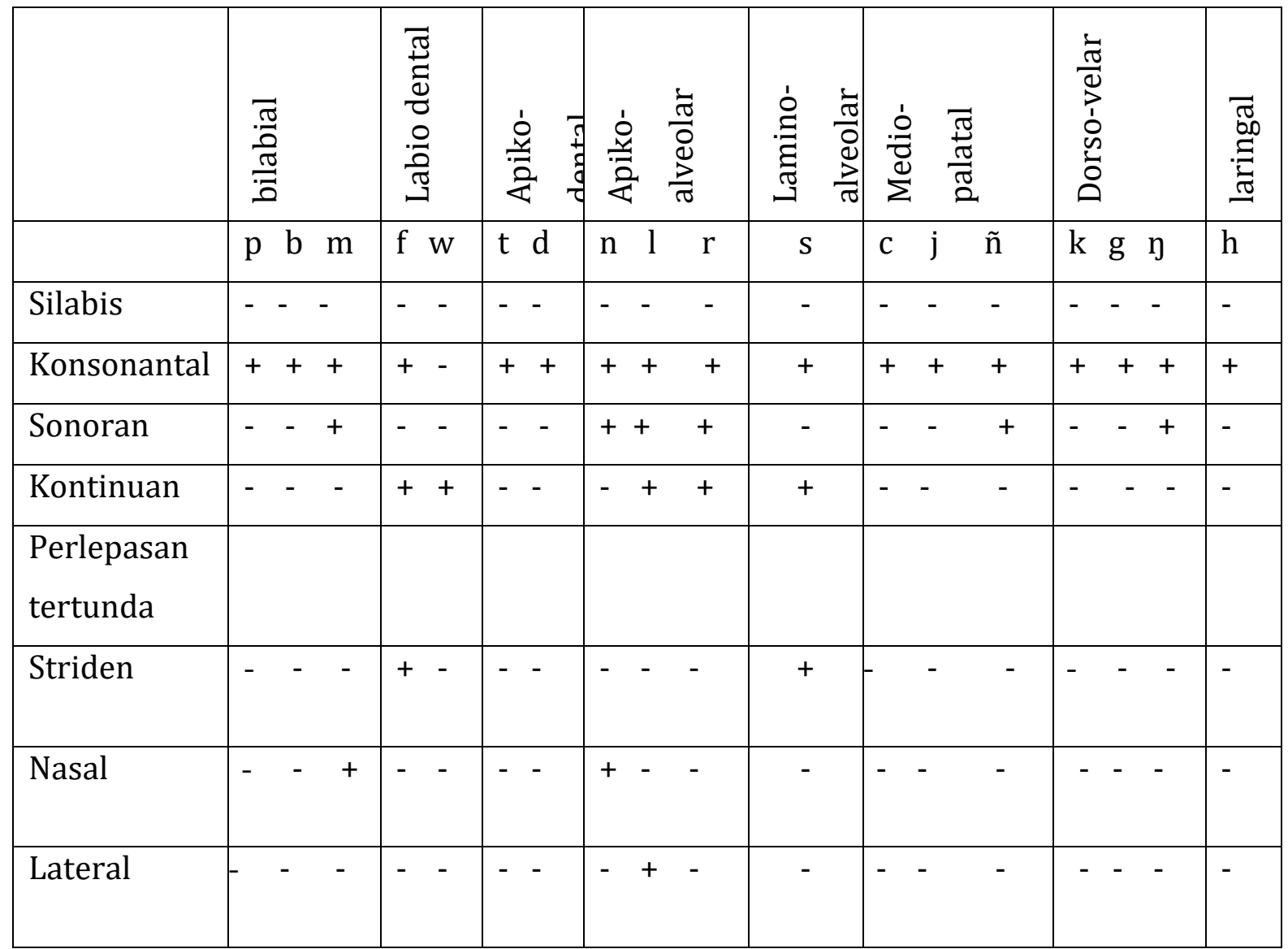


Jurnal Onoma: Pendidikan, Bahasa dan Sastra

PBSI FKIP Universitas Cokroaminoto Palopo

Volume 5 Nomor 1

\begin{tabular}{|c|c|c|c|c|c|c|c|c|c|c|c|c|}
\hline Anterior & +++ & + & ++ & + & + & + & - & & - & & - & - \\
\hline Koronal & - & & $-\quad-$ & + & + & + & + & & + & & - & - \\
\hline Tinggi & $-\quad-\quad-$ & & $-\quad-$ & - & - & - & + & & + & & + & - \\
\hline belakang & $-\quad-\quad-$ & & $-\quad-$ & - & - & - & - & 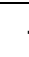 & & & + & - \\
\hline Bersuara & $-\quad+$ & & $-\quad+$ & + & + & - & - & - & & - & + & - \\
\hline
\end{tabular}

\section{Daftar Fonem Bahasa Massenrempulu}

\begin{tabular}{|c|c|c|c|c|c|c|c|c|c|c|c|c|}
\hline \multirow{2}{*}{$\begin{array}{c}\text { Cara } \\
\text { artikulas } \\
\text { i }\end{array}$} & \multirow{2}{*}{$\begin{array}{ll}\text { B } & \& \\
T & \end{array}$} & \multicolumn{11}{|c|}{ Tempat artikulasi } \\
\hline & & $\begin{array}{l}\frac{\pi}{0} \\
\frac{\pi}{0} \\
\frac{\pi}{0}\end{array}$ & $\begin{array}{l}\bar{\pi} \\
\stackrel{\pi}{0} \\
0 \\
.0 \\
\frac{0}{0} \\
\frac{\pi}{9}\end{array}$ & 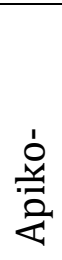 & 定 & 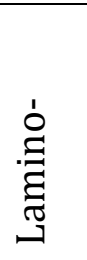 & $\begin{array}{l}\frac{\tilde{\pi}}{0} \\
\frac{0}{0} \\
\frac{\pi}{\pi}\end{array}$ & $\begin{array}{l}\stackrel{1}{c} \\
\stackrel{d}{d}\end{array}$ & $\begin{array}{l}\frac{\pi}{\pi} \\
\frac{\pi}{\pi} \\
\frac{\pi}{2}\end{array}$ & $\begin{array}{l}\bar{\pi} \\
0 \\
0 \\
0 \\
0 \\
0 \\
0\end{array}$ & $\frac{\sqrt[\pi]{\pi}}{3}$ & 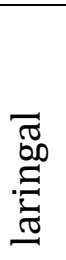 \\
\hline \multirow[t]{2}{*}{ Hambat } & $\mathrm{T}$ & $\mathrm{p}$ & & $\mathrm{t}$ & & & & $\mathrm{c}$ & & $\mathrm{k}$ & & \\
\hline & B & $\mathrm{b}$ & & $\mathrm{d}$ & & & & $\mathrm{J}$ & & $\mathrm{g}$ & & \\
\hline Nasal & B & $\mathrm{m}$ & & & $\mathrm{n}$ & & & $\tilde{n}$ & & $\mathrm{y}$ & & \\
\hline Lateral & B & & & & l & & & & & & & \\
\hline Frikatif & $\mathrm{T}$ & & $f$ & & & $\mathrm{~s}$ & 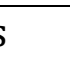 & & & & & $\mathrm{h}$ \\
\hline Getar & & & & & $\mathrm{r}$ & & & & & & & \\
\hline $\begin{array}{l}\text { Semi- } \\
\text { vokal }\end{array}$ & B & & w & & & & & & & & & \\
\hline
\end{tabular}

\section{Bagan Vokal Bahasa Massenrempulu}

\begin{tabular}{|l|c|c|c|}
\hline \multirow{2}{*}{$\begin{array}{l}\text { Posisi } \\
\text { lidah/bentuk bibir }\end{array}$} & Depan & \multicolumn{2}{|l|}{ Belakang } \\
\cline { 2 - 4 } & Tak Bulat & Tak Bulat & Bulat \\
\hline Tinggi & I & & u \\
\hline Tengah & E & & o \\
\hline Rendah & & a & \\
\hline
\end{tabular}


Jurnal Onoma: Pendidikan, Bahasa dan Sastra

PBSI FKIP Universitas Cokroaminoto Palopo

Volume 5 Nomor 1

\section{Posisi Kemunculan Dalam Kata}

\begin{tabular}{|c|c|c|c|c|}
\hline & $\#$ & —\# & $-\mathrm{K}$ & $\mathrm{v}$ \\
\hline $\mathrm{T}$ & + & - & - & + \\
\hline $\mathrm{C}$ & + & - & - & + \\
\hline
\end{tabular}

\begin{tabular}{|l|l|l|l|l|}
\hline & $\#-$ & $-\#$ & $\underset{\mathrm{K}}{\mathrm{K}}$ & $\mathrm{V}$ \\
\hline $\mathrm{C}$ & + & - & - & + \\
\hline $\mathrm{K}$ & + & + & + & + \\
\hline
\end{tabular}

\begin{tabular}{|c|c|c|c|c|}
\hline & $\#$ & —\# & $\mathrm{K}$ & $\mathrm{v}$ \\
\hline $\mathrm{d}$ & + & - & + & 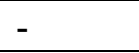 \\
\hline $\mathrm{j}$ & + & - & + & + \\
\hline
\end{tabular}

\begin{tabular}{|l|l|l|l|l|}
\hline & $\#-$ & $\longrightarrow$ & $\underset{\mathrm{K}}{\mathrm{K}}$ & $\mathrm{V} \longrightarrow \mathrm{V}$ \\
\hline $\mathrm{j}$ & + & - & + & + \\
\hline $\mathrm{g}$ & + & - & - & - \\
\hline
\end{tabular}

\begin{tabular}{|l|l|l|l|l|}
\hline & $\#-$ & $-\#$ & $-\mathrm{K}$ & $\mathrm{V}$ \\
\hline $\mathrm{p}$ & + & - & + & + \\
\hline $\mathrm{b}$ & + & - & - & + \\
\hline
\end{tabular}

\begin{tabular}{|l|l|l|l|l|}
\hline & $\#-$ & $-\#$ & - & $\mathrm{V}$ \\
\hline $\mathrm{t}$ & + & - & $+\mathrm{K}$ & + \\
\hline $\mathrm{d}$ & + & - & + & + \\
\hline
\end{tabular}

\begin{tabular}{|c|c|c|c|c|}
\hline & \# & —\# & ${ }^{K}$ & 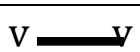 \\
\hline $\mathrm{c}$ & + & - & - & + \\
\hline j & + & - & + & + \\
\hline
\end{tabular}

\begin{tabular}{|l|l|l|l|l|}
\hline & $\#-$ & $-\#$ & $\underset{\mathrm{K}}{\mathrm{K}}$ & $\mathrm{V}$ \\
\hline $\mathrm{k}$ & + & + & + & + \\
\hline $\mathrm{g}$ & + & + & - & - \\
\hline
\end{tabular}

\begin{tabular}{|c|c|c|c|c|}
\hline & $\#$ & —\# & $\mathrm{K}$ & $\mathrm{V} \longrightarrow \mathrm{v}$ \\
\hline $\mathrm{m}$ & + & - & + & + \\
\hline
\end{tabular}

Halaman | 325 
Jurnal Onoma: Pendidikan, Bahasa dan Sastra

PBSI FKIP Universitas Cokroaminoto Palopo

Volume 5 Nomor 1

\begin{tabular}{|l|l|l|l|l|}
\hline $\mathrm{n}$ & + & + & - & + \\
\hline
\end{tabular}

\begin{tabular}{|l|l|l|l|l|}
\hline & $\#$ & $-\#$ & $-K$ & $V$ \\
\hline$\tilde{n}$ & - & - & - & + \\
\hline$\eta$ & + & + & - & + \\
\hline
\end{tabular}

\section{Kaidah Fonotaktik}

Dalam bahasa lisan, kata umunya terdiri atas rentetan bunyi, yang satu mengikuti yang lain. Bunyi-bunyi ini mewakilirangkain fonem serta alofonnya. Rangkain fonem ini tidak bersifat acak, tetapi mengikuti kaidah tertentu. Fonem yang satu yang dapat mengikuti fonem yang lain ditentukanberdasarkan konvensi di antara pemakai bahasa itu sendiri. Kaidah yang mengatur penjejeran fonem dalam satu morfem adalah kaidah fonotaktik

Pada bahasa massenrempulu,menggunakan kaidah dua jejeran konsonan dalam kata KK. KK inisial silabik ditemukan dalam bahasa ini dapat dilihat pada contoh berikut:

1. /nt/ (buntu)

2. /kt/ (cindaktu)

3. /nd/ (rundun).

\section{SIMPULAN}

1. Bahasa massenrempulu mengenal 5 buah vocal, yakni:

a. Vokal tinggi : : / u/

b. Vokal sedang : : / o/

c. Vokal rendah : : a/

2. Pada cerita rakyat Bellang Langi fonem-fonem yang terdapat dalam cerita tidak ada satu pun fonem yang menjadi alofon dari fonem lain.

3. Dalam cerita rakyat Bellang Langi terdapat beberapa fonem di antaranya konsonan bahasa massenrempulu mengenal 19 buah konsonan sedangkan semi vokal hanya terdapat satu fonem. Secara keseluruhan bahasa massenrempulu mengenal ada 24 fonem segmental 
Jurnal Onoma: Pendidikan, Bahasa dan Sastra

PBSI FKIP Universitas Cokroaminoto Palopo

Volume 5 Nomor 1

\section{DAFTAR PUSTAKA}

Chaer, Abdul. 2009. Fonologi Bahasa Indonesia. Jakarta: Rineka Cipta.

Chaer, Abdul. 2007. Linguistik Umum. Jakarta: Rineka Cipta.

Marsono. 1986. Fonetik. Yogyakarta: Gadjah Mada University Press.

Muslich, Masnur. 2011. Fonologi Bahasa Indonesia. Jakarta: Bumi Aksara.

Lass Roger.1991. Fonologi. Semarang. IKIP Semarang (Diterjemahkan oleh Drs.Warsono, M.A. dkk)

Suparman \& Charmilasari. (2016). Glotokronologi Bahasa Massenrempulu dan Bahasa Mandar, Prosiding Seminar Nasional UNCP Volume 2, 621-628.

Schane A. Sanford. 1992. Fonologi Generatif. Jakarta. Summer Intitute of Linguistic.

Verhaar, J. W. M. 2010. Asas-Asas Linguistik Umum. Yogyakarta: Gadjah Mada University Press 